\title{
Quarterly Summary Report October-December 1976 Process for Cleaning and Removal of Sulfur Compounds from Low Btu Fuel Cases
}

by

R. H. Moore

D. G. Ham

R. J. Robertus

January 1977

Prepared for the Energy Research and Development Administration under Contract E(45-1)-1830 


\title{
NOTICE
}

This report was prepared as an account of work sponsored by the United States Government. Neither the United States nor the Energy Research and Development Administration, nor any of their employees, nor any of their contractors, subcontractors, or their employees, makes any warranty, express or implied, or assumes any legal liability or responsibility for the accuracy, completeness or usefulness of any information, apparatus, product or process disclosed, or represents that its use would not infringe privately owned rights.

\author{
PACIFIC NORTHWEST LABORATORY \\ operated by \\ BATTELLE \\ for the \\ ENERGY RESEARCH AND DEVELOPMENT ADMINISTRATION \\ Under Contract EY-76-C-06-1830
}

\author{
Printed in the Linited States of America \\ Available from \\ National Technical Information Service \\ U.S. Department of Commerce \\ 5285 Port Royal Road \\ Springfield, Virginia 22151
}

Price: Printed Copy S__ ; Microfiche $\$ 3.00$

- Pages

NTIS

Selling Price

$001-025=\$ 4.50$

026-050 $\quad \$ 5.00$

$051-075 \quad \$ 5.50$

$076-100 \quad \$ 6.00$

$101-125 \quad \$ 6.50$

$126-150 \quad \$ 7.00$

$151-175 \quad 57.75$

$176-200 \quad 58.50$

$201.225 \quad 58.75$

$226-250 \quad 59.00$

$251-275 \quad \$ 10.00$

$\begin{array}{ll}276-300 & \$ 10.25\end{array}$ 
BNWL -2040-4

33679000625105

UC-90c

\title{
QUARTERLY SUMMARY REPORT \\ OCTOBER-DECEMBER 1976 \\ PROCESS FOR CLEANING AND REMOVAL OF SULFUR COMPOUNS ROM LON \\ BTU FUEL GASES
}

\author{
by \\ R. H. Moore \\ D. G. Ham \\ R. J. Robertus
}

January 1977

BATTELLE

Pacific Northwest Laboratories

Richland, Washington 99352 


\section{QUARTERLY SUMMARY REPORT \\ OCTOBER-DECEMBER 1976 \\ PROCESS FOR CLEANING AND REMOVAL OF SULFUR \\ COMPOUNDS ROM LOW BTU FUEL GASES}

R. H. Moore, D. G. Ham, and R. J. Robertus

\section{I - OBJECTIVE AND SCOPE OF WOFK PHASE IV}

In this phase of work the PDU is to be remodeled by incorporation of appropriate subsystems to permit operation in continuous process mode. The PDU will be operated for a period of time sufficient to demonstrate process viability.

\section{I. SUMMARY}

(1) Completion of the design of the electrical circuitry brings the design phase of the work to a virtual close. Minor design work remaining involves the air preheater, steam- $\mathrm{CO}_{2}$ preheater, and sampling systems.

(2) Contracts were negotiated with a local firm for remodeling the support structure and increasing the exhaust stack height by 20 feet and with a Portland concern for fabrication of all pipe and equipment which must be "alonized."

(3) The regeneration and extraction columns and trace heaters for which orders were placed earlier were received in good condition. In addition the Spectra Physics SP-4000 Central Processor (Integrator), SP-4050 Printer-Plotter, and two SP-4020 Data Interface Units to be utilized in control of our gas chromatographs have been received.

(4) A theoretical analysis of the effect of an increase in pressure to 20 atmospheres on the number of extraction 
and regeneration stages required is in progress. This process has so much flexibility in choice of salt composition and flow that little if any change in staging seems indicated.

(5) The complexity of this project has made it necessary to have recourse to planning techniques for effective management. A Precedence Diagram has been constructed to assist in control of scheduled work. Certain complex tasks identified in the Precedence Diagram have been diagrammed in greater detail by means of PERT techniques.

(6) Numerous minor tasks, e.g., preparation of bid packages, supervision of contract awards, preparation of numerous small procurement orders (gaskets, nuts, bolts, small hardware), equipment modification, and site preparation were completed during the report period.

\section{TECHNICAL PROGRESS}

A. Plant Design and Procurement

The increased complexity of the remodeled PDU and longer lengths of pipe result in a much larger resistive heating load than was true of the older plant. The trace heating has been broken down into 26 furnaces with separate controls. Load switching relays, solid state proportioning controllers and chromel-alumel thermocouple sensors will be used for control. Circuit breakers will provide overload protection. Relays and circuit breakers from the old installation, as well as a 75 KVA transformer, will be utilized, but substantial new circuit breaker panel and relay rack service will be needed.

During operation of the PDU, the primary transformer (nominal 250 KVA capacity) will be paralleled with a loaner transformer (provided by the City of Richland, Utilities Department). This might not be required if operation were limited to cool weather. A July 1, 1977 start for shakedown 
runs is planned and this region could experience $100^{\circ} \mathrm{F}$ daytime temperatures which reduce the overload margin of safety in transformer operation.

In addition to the thermocouple sensors connected to solid state proportioning controllers, there will be numerous thermocouples spotted throughout the plant. There are 16 on the gasifier, 4 on the steam- $\mathrm{CO}_{2}$ preheater, and 40 on the piping and vessels which comprise the PDU. A 24-point recorder was adequate for monitoring thermocouples in the earlier plant configuration but for the new plant it becomes more economical to select digital readout devices. It is not really necessary to record and store the information from all these thermocouple sensors. It is only necessary to be able to take the reading and, if not in the right range, take appropriate action. Specifications on various makes of equipment to provide this capability are under review.

At present, draftsmen are preparing working drawings of the electrical system from which the electricians can work. A detailed lis t of equipment required (with specifications) has been prepared by Mr. Lee Higginson, an electrical engineer in our Facilities Engineering Department who has designed the electrical circuitry for the remodeled PDU. Procurement of this equipment will be initiated shortly.

During this report period certain equipment installations have been cleared from the plant site to facilitate construction. These include the coke pile and coke bin containing about 6 tons of coke and the aqueous $\mathrm{Na}_{2} \mathrm{CO}_{3}$ scrubber system used to extract $\mathrm{H}_{2} \mathrm{~S}$ from gases produced during batch regeneration of molten salt. The latter consists of a 100 gal. black iron tank, an $8 \mathrm{in}$. dia by $90 \mathrm{in.}$ tall column packed with $1 \mathrm{in}$. stainless steel Pall rings, a circulating pump, and various pipe connections. It is planned to salvage the column for use as a low temperature $\left(400^{\circ} \mathrm{C}\right)$ air preheater to provide air to the salt cooler.

The large $(2000 \mathrm{lb})$ pot furnace now installed on the first level above grade is to be removed and installed on the second level above grade. This move will be performed by the contractor during construction of the 
new support structure. To facilitate this work, the old packed bed deentrainer and pot cover assembly has been removed from this furnace and pipe leading from the pot to the venturi scrubber taken down. This allowed removal of the pot from this furnace, freeing it from all equipment connections. The furnace has also been disconnected electrically.

All existing structure above the grid on which the furnace presently sits is to be replaced by new structure. It was necessary to remove a few wires, pipe, and tubing runs from this area to facilitate construction.

The packed bed de-entrainer and the pot which were removed from the furnace will be salvaged, modified, and reused. The packed bed de-entrainer has been cut off the old pot cover. The area of the cut has been trued in a lathe and machined to remove "alonized" material. A 10 in. flange was then welded to the reducer section of the de-entrainer. This flange will permit installation of the de-entrainer on top of the extraction column.

A new packing support grid and a new thermocouple well will be installed in the de-entrainer. The unit will then be cleaned thoroughly by sand blasting, crated, and shipped east for "alonizing."

The $24 \mathrm{in}$. diameter "alonized" pot has a $1 \mathrm{in}$. exit line welded into the bottom. This line needs to be fitted with a grayloc hub in place of the existing standard flange. This modification will be made and the pot will also be sandblasted to clean it. The old pot cover is to be replaced with a new one fabricated from a standard $24 \mathrm{in}$. dia pipe cap. The pipe cap is currently being fitted with various inlet lines and fittings by Metaltronics Inc. as part of their pipe and equipment fabrication subcontract. When delivered the cap will be welded to the "alonized" pot taking care to grind or machine the "alonized" layer away from the weld zone. The completed assembly will have to be "alonized."

This "alonized" pot has received exposure to sulfur bearing molten carbonate mixtures at temperatures ranging from $700^{\circ}-816^{\circ} \mathrm{C}$ for a total 
period approaching $100 \mathrm{hr}$ with no detectable corrosion. It will be realonized along with the cover and grayloc hub assembly.

The subcontract for pipe and equipment fabrication is reported by the contractor (Metaltronics Inc., Portland, OR) to be about 25 percent completed. A potential exists for delay in completion due to possible delay in obtaining needed grayloc hubs from Gray Tool Company, the sole source. An effort is being made to assist Metaltronics in expediting this order.

The subcontract for remodeling the support structure was awarded to a local concern (Tri-Cities Machine and Fabrication, Pasco, WA). This work is nearing completion. In shop fabrication (preassembly) is complete and the contractor moved material and equipment to the site 1/5/77 and expects to complete the assembly within two to three days. If so, this work will be completed in advance of schedule.

\section{B. Theoretical Supporting Studies}

Various sources critical of molten salt processes have criticized this process on the grounds that it is inapplicable at high pressure. This conclusion arises from consideration of the reaction:

$$
\mathrm{M}_{n} \mathrm{CO}_{3}+\mathrm{H}_{2} \mathrm{~S} \stackrel{\rightarrow}{ } \mathrm{M}_{n} \mathrm{~S}+\mathrm{H}_{2} \mathrm{O}+\mathrm{CO}_{2} \text {. }
$$

Clearly, two moles of gaseous products are generated from reaction of but one mole of gas, so the reaction will be pressure dependent. Thus an increase in pressure from 1 to 20 atm should result in a 20 -fold increase in the equilibrium concentration of $\mathrm{H}_{2} \mathrm{~S}$. This conclusion is applicable only to single stage extraction. Single stage regeneration, the reverse of reaction (1), would benefit from an increase in pressure.

The question which should be asked is: "How will an increase in pressure affect multistage extraction of $\mathrm{H}_{2} \mathrm{~S}$ and regeneration of the salt?" This question is not simple to answer, but considerable progress has been made and preliminary results are outlined below. 
The following assumptions have been made:

(1) Gas handling capacity was $75 \mathrm{SCFM}$ with 1.3 mole $\% \mathrm{H}_{2} \mathrm{~S}, 5$ mole $\% \mathrm{CO}_{2}$, and 10 mole $\% \mathrm{H}_{2} \mathrm{O}$ in gas entering the venturi scrubber.

(2) The co-current flow contactor (venturi scrubber) and supplementary counter current flow contactor (bubble cap tray column) operate at $700^{\circ} \mathrm{C}$ and $20 \mathrm{~atm}$ pressure.

(3) The regenerator (a bubble cap tray column) operates at $550^{\circ} \mathrm{C}$ and 20 atm pressure.

(4) $\mathrm{Na}_{2} \mathrm{CO}_{3}$ was assumed to be the only active species in the ternary eutectic mixture.

(5) The venturi would remove 60 percent of the $\mathrm{H}_{2} \mathrm{~S}$ in the gas and operate at 80 percent of equilibrium. (This fixes the $S$ content of salt entering the generator).

(6) Total extraction of $\mathrm{H}_{2} \mathrm{~S}$ must equal 98 percent.

(7) The $S$ concentration in salt fed to the extraction column will be at 80 percent of equilibrium with gas leaving the column (as in the case of the regeneration column, this fixes the concentration of $S$ in salt entering the extraction column and material balances then serve to establish the salt flow rate).

The above assumptions were identical to those used in design of this process for operation at $1 \mathrm{~atm}$. This was done to simplify direct comparison. Table 1 summarizes the comparison between operation at high and low pressures in the case of the regeneration and extraction columns.

The results indicate an increase in the number of extraction stages from 1.5 to 4.8, fewer regeneration stages, and an increase in salt flow through the regeneration and extraction columns of about an order of magnitude. Thus, no recycle flow is required.

Efficiency calculations for the 1 atm case were based on actual tray configurations and some consideration of theoretical mass transfer 
TABLE 1. Behavior of Bubble Cap Tray Columns for Extraction and Regeneration of High and Low Pressures

\begin{tabular}{|c|c|c|c|c|}
\hline \multirow{2}{*}{ Gas Flow } & & \\
\hline & $1 \mathrm{Atm}$ & $20 \mathrm{Atm}$ & $1 \mathrm{Atm}$ & $20 \mathrm{Atm}$ \\
\hline \multicolumn{5}{|l|}{$\ln \mid e t$} \\
\hline Total Moles/Hr & 1.47 & 1.49 & 12.67 & 12.63 \\
\hline $\mathrm{H}_{2} \mathrm{~S}$, Mole $\%$ & 0 & 0 & 0.36 & 0.52 \\
\hline \multicolumn{5}{|l|}{ Outlet } \\
\hline Total, Moles/Hr & 1.37 & 1.33 & 12.71 & 13.0 \\
\hline $\mathrm{H}_{2} \mathrm{~S}$, Mole $\%$ & 12 & 12 & 0.05 & 0.026 \\
\hline \multicolumn{5}{|l|}{ Salt Flow } \\
\hline \multicolumn{5}{|l|}{ Inlet } \\
\hline Total, Moles/Hr & 1.24 & 10.23 & 1.24 & 10.23 \\
\hline $\begin{array}{l}\quad M_{n} S \text {, Mole \% } \\
\text { Outlet }\end{array}$ & 13.6 & 1.63 & 0.89 & 0.069 \\
\hline Total, Moles/Hr & 1.24 & 10.23 & 1.24 & 10.23 \\
\hline$M_{n} S$, Mole $\%$ & 0.89 & 0.069 & 4.19 & 0.68 \\
\hline Temp ${ }^{\circ} \mathrm{C}$ & $550<T<617$ & 557 & 700 & 700 \\
\hline Theoretical Stages & 3.0 & 1.5 & 1.5 & 4.8 \\
\hline Overall Efficiencies, \% & 78.5 & & 98.8 & \\
\hline
\end{tabular}


coefficients. This calculation is quite tedious and has not been attempted, as yet, for the 20 atm case.

If the assumption that overall $\mathrm{H}_{2} \mathrm{~S}$ recovery must be 98 percent is modified to allow recovery of but 90 percent of the $\mathrm{H}_{2} \mathrm{~S}$, the required extraction stages become 2.6. In many cases, 90 percent overall recovery of $\mathrm{H}_{2} \mathrm{~S}$ would be acceptable

Addition of $\mathrm{CaCO}_{3}$ to the ternary alkali carbonate eutectic will increase the extraction coefficient. In the range of 15-20 mole percent $\mathrm{CaCO}_{3}$ a 30-40 fold increase in extraction coefficient should be observed. The increased extraction efficiency will permit reduced salt flow and a reduction in the number of extraction stages required. Regeneration efficiency will be reduced but the number of regeneration stages required is not likely to become excessive. Continued analysis of this problem is contemplated to firm the conclusions outlined here.

\section{Program Management}

Even a small pilot plant construction program such as this can raise complex problems in scheduling the activities so as to maintain control of costs and schedule. To clarify matters, the activities essential to this program have been outlined in Precedence Diagram format, Figures $\mathrm{I} a$ and $\mathrm{Ib}$. Boxes are shown containing a descriptive title of the task. Numbers above the title identify the cost center, and numbers below the title are actual or estimated man-hours required for task performance. Boxes shown with crosshatching identify tasks which lie along a critical path. The boxes are not to scale (timewise) though the position of the end closure of a box along the time scale represents a schedule we will strive to maintain for those tasks along the critical path.

Some of these tasks are fairly complex, e.g., the task on the critical path ending about the third week in February 1977 entitled "Instal Columns and Piping, Dismantle and Crate" (460 man-hours). This task has been further resolved by PERT (Program Evaluation and Review Technique) 
diagramming. The task cannot begin until the support structure is remodeled. It cannot be completed until all pipe and equipment now being fabricated under subcontract is received. Metaltronics Inc. is scheduled to complete equipment fabrication by $2 / 15 / 77$. The PERT technique dis closes the task completion deadline cannot be met with such a late start, because sufficient manpower to complete the work within schedule cannot be made available. The pressure on manpower can be reduced if partial delivery at an earlier date of some of the order can be made. Items not being delayed (e.g., by Gray Tool Company) can be shipped early. Metaltronics has agreed to this and the work can be rescheduled accordingly, i.e., the PERT diagram can be revised.

\section{PROPOSED WOFK DURING THE NEXT QUARTER}

Major emphasis during the next quarter will be placed on completion of the preassembly task and getting the pipe and equipment "alonized" on schedule. Numerous procurement actions are scheduled, especially electrical gear, and installation of some of this will be initiated. Design of the air preheater, steam- $\mathrm{CO}_{2}$ preheater, and salt spill collector troughs is planned.

\section{OVERALL PROJECT STATUS AND CONCLUSIONS}

During the quarter major procurements were initiated, including all pipe and equipment to be "alonized" and the support structure. The extraction and regeneration columns and most of the required trace heating were received as were major analytical control instrumentation. Numerous procurements remain, but the project is now moving from a design into a construction phase. The schedule has been updated and displayed in Precedence Diagram format which discloses the details of the work completed and remaining. This diagram will be updated quarterly. 


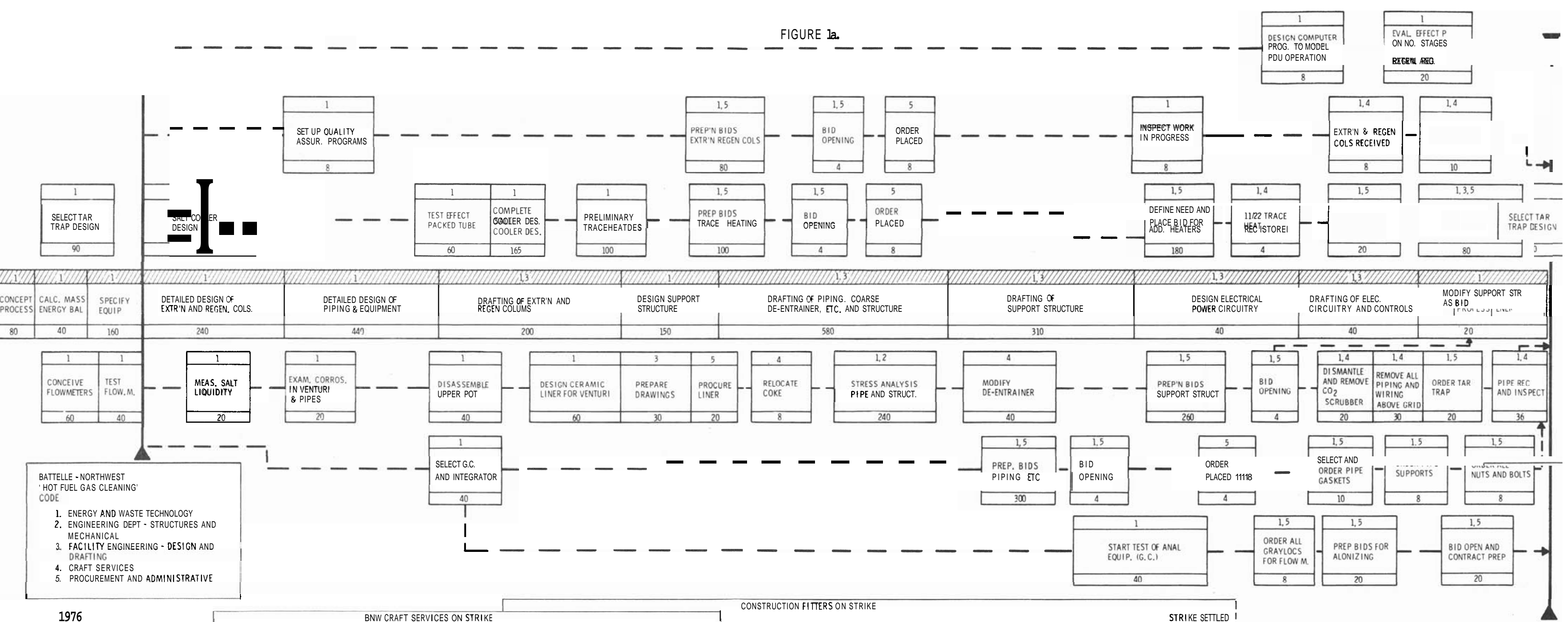

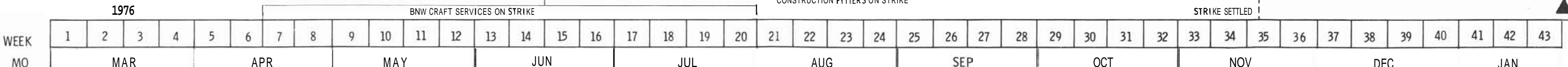




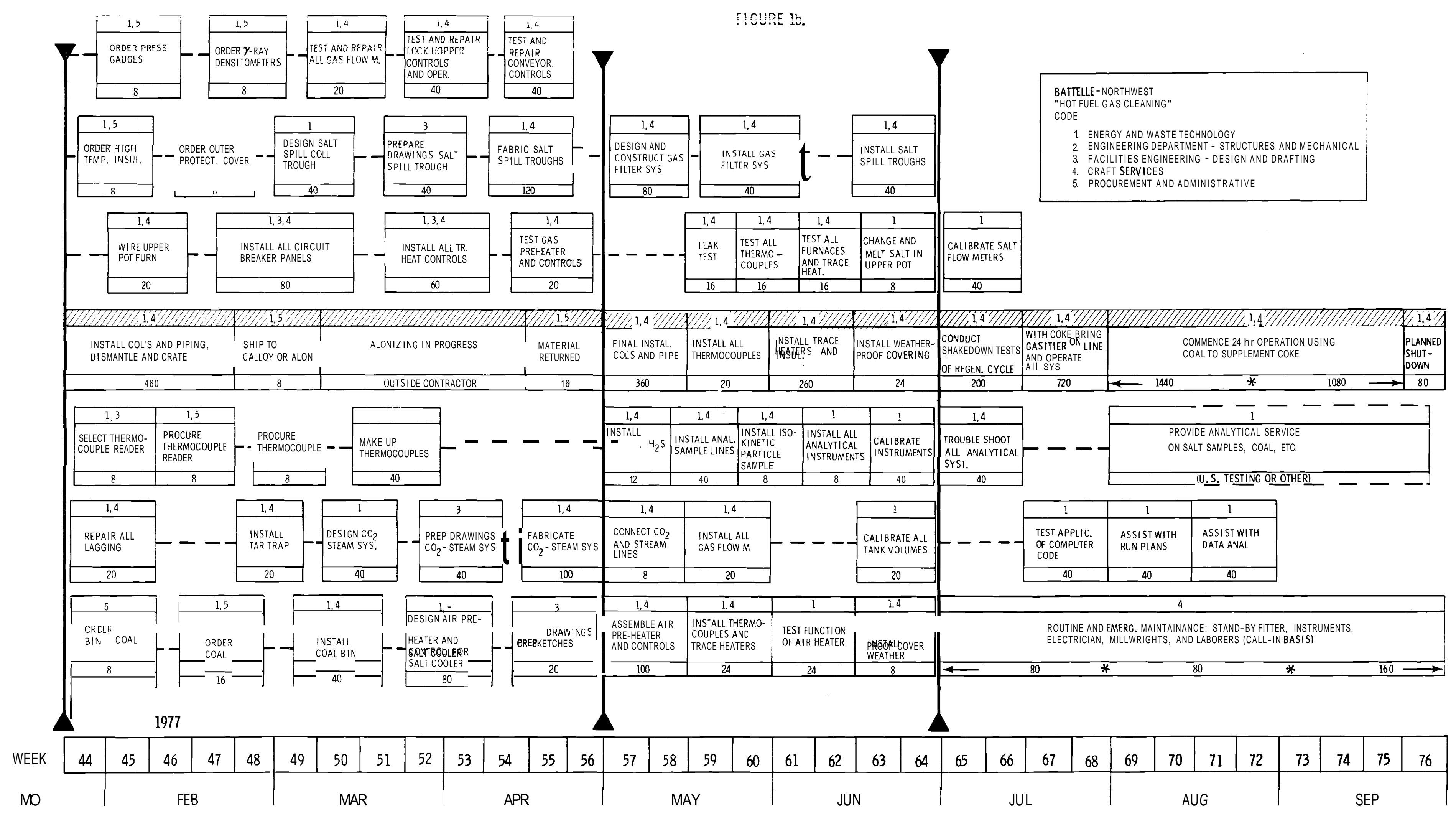


BNWL-2040-4

UC $-90 \mathrm{c}$

\section{DISTRIBUTION}

No. of

Copies

OFFS ITE

A. A. Churm

ERDA Chicago Patent Group 9800 South Cass Avenue

Argonne, IL 60439

5 Dr. Michael Gurevich ERDA Fossil Energy 20 Massachusetts Avenue Washington, DC 20545

27 ERDA Technical Information
No. of

Copies

ONSITE

2 ERDA Richland Operations Office Programs Division

Harold Ransom

Fred Goldsberry

16 Battelle-Northwest

C. H. Allen

G. A. Halseth

D. C. Ham

R. L. Maness

R. H. Moore (3)

R. E. Nightingale

C. A. Rohrmann

R J. Robertus

G. L. Stegen

P. C. Walkup

Technical Publications (1)

Technical Information Files (3) 